\title{
高レベル放射性廃棄物地層処分施設の立地調査受容に信頼と手続き的公正が 及ぼす影響
}

\author{
大澤 英昭（日本原子力研究開発機構 核燃料・バックエンド研究開発部門, ohsawa.hideaki@jaea.go.jp） \\ 大友 章司（甲南女子大学人間科学部, s.ohtomo@konan-wu.ac.jp） \\ 広瀬 幸雄（関西大学 社会安全学部, yhirose@kansai-u.ac.jp） \\ 大沼 進（北海道大学大学院文学研究院, ohnuma@1et.hokudai.ac.jp）
}

Effects of trust and procedural fairness on public acceptance of siting a repository for high-level radioactive waste Hideaki Osawa (Sector of Nuclear Fuel, Decommissioning and Waste Management Technology Development, Japan Atomic Energy Agency, Japan) Shoji Ohtomo (Faculty of Human Sciences, Konan Women's University, Japan)

Yukio Hirose (Faculty of Societal Safety Sciences, Kansai University, Japan)

Susumu Ohnuma (Graduate School of Letters, Hokkaido University, Japan)

\begin{abstract}
This study examined the determinants of public acceptance of siting a repository for High-level radioactive waste (HLW), focusing on procedural fairness and trust. The study presumed that interactive effect of procedural fairness $\times$ trust on public acceptance exist. To examine the presumption, the study implemented a hypothetical scenario experiment that manipulated two factors: an opportunity of voice as an antecedent of procedural fairness and value similarity to the authority as a component of trust. Three-hundred seventeen people participated in the web-based experiment. Participants were randomly assigned to one of four conditions: procedural fairness (voice vs. no voice) $\times$ trust (similarity vs. no similarity) factorial design associated with acceptance of siting investigation for a repository of HLW. The experiment measured affective reaction to the siting, and evaluations of procedural fairness, trust, public acceptance in the decision-making process. Results indicated that affective reaction, procedural fairness, and trust determined public acceptance. Moreover, the interactive effect of procedural fairness $\times$ trust on public acceptance was found. A process analysis indicated that the effect of procedural fairness was strengthened when the trust on similarity was negative.
\end{abstract}

\section{Key words}

public acceptance, procedural fairness, trust, high-level radioactive waste, siting

\section{1. はじめに}

原子力発電に伴って発生する高レベル放射性廃棄物 (High-level radioactive waste ; 以下、HLW) は、時間とと もに放射性崩壊によって減衰するものの、その潜在的危 険性は数万年以上継続するといった特徵を有するため、 HLW 地層処分施設建設地の選定は困難な課題の一つとし てあげられる。Easterling（2000）によれば、HLW 地層処 分施設は、刑務所や原子力発電所といった NIMBY (Not In My Back Yard）（鈴木，2011）施設に比べて最も忌避的 な施設として人々から評価される。HLW 地層処分施設の 立地については、1990 年代以降、「参加し、交流し、協 力する」という双方向なリスクコミュニケーションにそ のやり方を変化させ、改めて取り組みが行われ（NEA， 2013)、フィンランドやスウェーデンでは候補地が決まっ た。しかし、必ずしも全ての国で候補地が決まったとい うわけではない（経済産業省資源エネルギ一庁, 2018）。

原子力発電や放射性廃棄物の貯蔵施設などのリスク 受容において、手続き的公正の影響を重視する立場と (Basely, 2012 など)、手続き的公正の影響を限定的とする
立場がある（Earle \& Siegrist, 2008）。中・低レベルの放射 性廃棄物の貯蔵管理施設の事例（Krütli, Flüeler, Stauffacher, Wiek, \& Scholz, 2010) や、高レベル放射性廃棄物の最終 処分場の事例 (大友 - 大澤 - 広瀬 - 大沼, 2014 ; 大澤 - 広 瀬・大沼・大友，2014）において、公正な手続きが決定受 容において重要な要因であることが指摘されている。

一方で、信頼が科学技術の受容を規定する重要な要因 であることはさまざまな研究によって指摘されている (Earle, 2010 など)。原子炉の建て替えの研究では、福島 原発事故前後で信頼が先行要因として同じように影響を 及ぼしていたことが報告されている（Visschers \& Siegrist, 2013)。また、HLW 地層処分施設の立地受容に関する研 究 (大友他, 2014 ; 大澤他, 2014）では、信頼は先行要因 として他の規定因に影響を与えるが、立地受容には直接 的な影響を与えていない。

以上の研究では、手続き的公正あるいは信頼の単独の 効果をそれぞれ検討しているが、手続き的公正と信頼の 両方の要因をとりあげて、その交互作用的な影響を検討 していない。どのような場合に手続き的公正あるいは信 頼のいずれが立地受容により大きな影響を及ぼすのかを 明らかにするために、2つの要因の組み合わせ要因を統制 した実験的研究が必要である。 


\section{2. 本研究の目的}

原子力発電所や HLW 地層処分施設の受容の規定因とし て、信頼を重視する立場と手続き的公正を重視する立場 の 2 つの理論的枠組みがある。原子力発電所や HLW 地層 処分施設などの忌避的な施設以外の分野のリスク受容に おいては、例えば、広瀬・大友（2015）が、ごみ収集料 決定受容に関し、行政への信頼が低い場合には、高い場 合よりも、手続き的公正の評価が值上げの受容に及ぼす 効果が大きくなる信頼の調整要因を指摘するなどしてい るが、忌避的な施設のリスク受容に関しては、どのよう な状況で信頼、あるいは手続き的公正が主要な規定因に なるのか、また、両要因の組み合わせによる交互作用は ごうなのか、心理学的に条件を操作して検討する研究が 行われていない。そこで、本研究では、HLW 地層処分施 設の立地調査受容を取り上げて、信頼や手続き的公正が 規定因としてどのように決定受容に影響を及ぼすのか検 討することを目的とする。

Peters, Burrastonm, \& Mert（2004）は、原子力発電につ いて，受容できる／受容できない，名誉である／不名誉 であるといった評価に対して感情の影響があることを示 している。Finucane, Alhakami, Slovic, \& Johnson（2000）は、 肯定的な感情を喚起させる対象は「リスク認知が低く、 便益認知が高く」、否定的な感情を喚起させる対象には「リ スク認知が高く、便益認知が低い」という判断が生じや すくなるなど、感情がバイアスを生じさせることを指摘 している。また、HLW 地層処分施設の立地受容に関しても、 立地受容に直接影響を与えたり（大澤他, 2014）、様々な 規定因のバイアスになることが指摘されている（大友他, 2014)。

これまで，原子力政策の受容の研究において、怒りと いった感情的反応が強い人ほど、手続き的公正の決定受 容に対する影響が強くなることを指摘されている（Besley， 2012)。特に、放射性廃棄物の問題は忌避的な反応が生じ やすい（Easterling, 2001)。施設の立地の問題を务威に感 じているほじ、否定的な感情が強くなり、より公正な手 続きのよる決定を求める傾向は強くなる可能性がある。 一方で、決定受容において信頼の影響力の方が強く、手 続き的公正は個人にとって重要な問題では影響力が弱く なることを示唆する研究もある（Earle \& Siegrist, 2008）。

そこで, 本研究では、HLW 地層処分施設の立地調査 が求められている地域の人々が抱いている感情的評価の 影響も含め、手続き的公正や信頼の決定受容に対する影 響について、場面想定法によるシナリオ実験により検討 を加える。具体的には、立地調査地域の人々の感情的評 価の測定に加え，手続き的公正の高低を操作したシナ リオと，信頼の高低を操作した決定プロセスのシナリオ の 4 つの条件を設定する。その際，手続き的公正は、意 思決定者が人々の考えをどれくらい尊重するかの意見反 映（van den Bos, 1999）により操作する。実際に、社会 的決定のシナリ才実験により，意見反映が手続き的公正 を左右する要因であることが確認されている（Nonami, Hirose, Ohnuma, Midden, \& Ohtomo, 2015; van den Bos, Maas,
Waldring, \& Semin, 2003)。また、信頼は、意思決定者が自 分と意見や考えがじれくらい類似しているかの価值類似 性（Earle \& Cvetkovich, 1995）により操作する。これまで、 リスクの問題において、価值類似性が信頼を規定する重 要な先行要因であることが指摘されている（Cvetkovich \& Nakayachi, 2007; Earle \& Siegrist, 2008)。また、シナリオ実 験おいても、価值類似性が信頼を左右する要因であるこ とが示唆されている（Nonami et al., 2015）。これらの操作 を行い、信頼や手続き的公正の違いにより、立地調查の 是非の決定がどのように受容されるのか検討を加える。

\section{3. 方法}

\section{1 実験の参加者}

実験は、クロス・マーケティング社の首都圏のモニター から合計で 600 名程度を目標に、実験条件ごとに性別（男 性、女性） $\times$ 年代（20 代、40 代、50 代、60 代）ごとに 募集された。最終的に欠損值のない有効分析サンプルは 317 であった。

\section{2 実験デザイン}

過疎化に直面している $\mathrm{A}$ 市の市長が、地層処分施設の 立地調查の申し入れに対し、その受け入れを判断すると いう仮想的場面において、A 市の市長が自分と考えが類 似しているか否かの類似性（価值類似性）（高群 vs. 低群） × A 市の市長が市民の意見を尊重するか否かの意見反映 （高群 vs 低群）の 4 条件が設定された。

\section{3 実験手続き}

一連の実験の流れを図 1 に示す。実験参加者は、まず、 HLW 地層処分を説明した画面を提示した後、処分場に対 する感情的評価を行った。次に、「A 市の市民」という設 定で、「政府から HLW 地層処分場の候補地になるための 立地調査の受け入れが要請された」という場面を説明し た画面が提示された（Appendix 1)。

その次に、意見反映による手続き的公正と市長への価 值類似性による信頼がシナリオにより操作された。意見 反映による手続き的公正と市長への価值類似性による信 頼の操作の順序はカウンターバランスがとられている。 意見反映による手続き的公正の操作（Appendix 2）では、 「市民の意見を聴き、その意見を尊重して、地層処分場の 立地調査の受け入れの是非を決める手続きで進めていく」 （高群）と「市長自身の判断で、地層処分場の立地調査の 受け入れの是非を決める手続きで進めていく」（低群）に より操作された。価值類似性による信頼の操作（Appendix 3）では、「A市の発展についてあなたとは同じような意 見の持ち主です、あなたと同様な判断をする」（高群）と 「A市の発展についてあなたとは違った意見の持ち主で す、あなたと違った判断をする」(低群)により操作された。 この実験操作の後、市長への信頼、手続き的公正、受け 入れの是非、個人属性が測定された。最後にデブリーフィ ングの画面が提示された。 


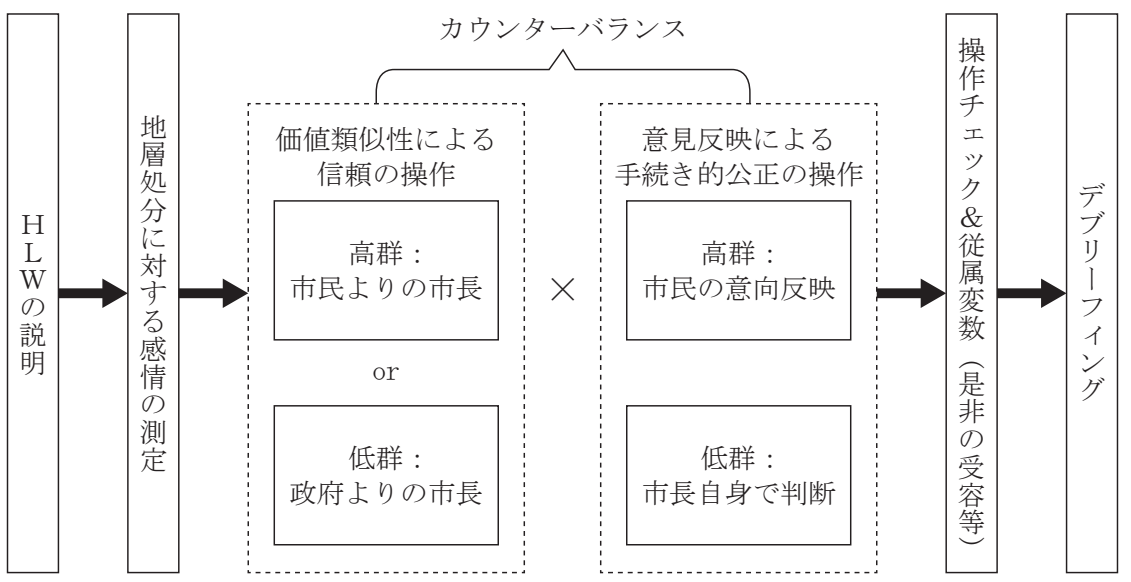

図 $1:$ 実験手続きの流れ

\section{4 測定変数}

\subsection{1 感情的評価}

高レベル放射性廃棄物の地層処分について印象につい て、「よい〜わるい」、「すきな〜きらいな」、「好ましい〜 好ましくない」、感じのわるい〜感じのよい」、「必要な 〜不必要な」、「危険な〜安全な」、「無害な〜有害な」、「不 安定な〜安定な」、「あぶなくない〜あぶない」、「問題の ある〜問題のない」の 10 項目の 5 段階評価の SD 尺度に より測定した $(\alpha=.94)$ 。得点が低いほど否定的な感情的評 価で、高いほど肯定的な感情的評価をするように算出し た。

\section{4 .2 信頼}

A 市の市長について、「A 市の市長は、最終処分場に関 する判断を適切に行う能力があるだろう」、「A市の市長 は、市民のことを考えて決定を行うだろう」、「A市の市 長は、あなたと同じような目線に立っているだろう」、「A 市の市長の考えは、あなたと一致しているだろう」、「A 市の市長の判断は、信頼できる」、「A市の市長は、頼り になる」の 6 項目を、“1. 全くそう思わない”から“5. 非 常にそう思う”の 5 段階尺度で測定した $(\alpha=.92)$ 。

\section{4 .3 手続き的公正}

A市の市長の進め方について、「A 市の市長の最終処分 場の候補地調査の受け入れの是非を決めるやり方は望ま しい」、「A 市の市長の最終処分場の候補地調查の受け入 れの是非を決める進め方は公正だ」、「A 市の市長の最終 処分場の候補地調査の受け入れの是非を決める手続きは、 全体に評価できる」の 3 項目を、“1. 全くそう思わない” から“5. 非常にそう思う”の 5 段階尺度で測定した $(\alpha=$ $.93)$ 。

\subsection{4 決定受容}

最終処分場の候補地調査の受け入れの是非が決定した 場合に、「私は、その決定を受け入れられるだろう」、「私 は、その決定をそれで良いと認めることができるだろう」、
「私は、その決定を納得することができるだろう」、「私は、 その決定に抵抗を感じるだろう」、「私は、その決定を支 持するだろう」、「その決定について、賛否を問う住民投 票が行われれば、賛成票を入れる」の 6 項目を、“1. 全く そう思わない”から“5. 非常にそう思う”の 5 段階尺度 で測定した $(\alpha=.92)$ 。

\section{4 .5 個人属性}

モニター情報に含まれていないサンプリング項目（年 齢、性別）を除く、職業、学歴、家族構成（子どもの有無） について測定した。

\section{4. 結果}

\section{1 操作チェック}

まず、実験条件間で性別（男性 $48 \%$, 女性 $52 \%, \chi^{2}(1)$ $=.57, p=.299)$ 、年齢 $(M=44.61, S D=13.48, F s<.31)$ に 違いがないことが確認された。

次に、実験操作前の要因である感情的評価にも、実験 条件で違いを検討したところ、価值類似性 $\times$ 意見反映の 交互作用のみが確認された $\left(F(1,313)=5.86, p=.016, \eta_{p}^{2}\right.$ $=.02)$ 。この交互作用について、単純主効果の検定を行っ

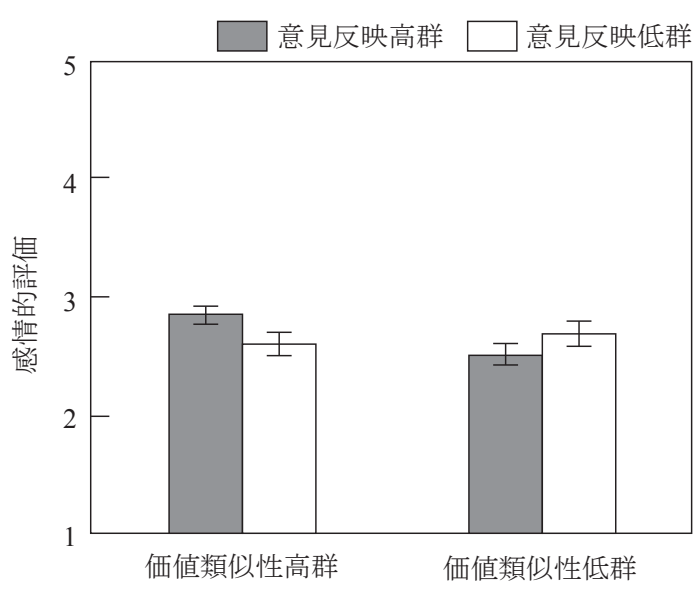

図 2 : 感情的評価の各条件の平均值 
たところ、価值類似性高群における意見反映の効果が確 認された $\left(F(1,313)=4.94, p=.027, \eta_{p}^{2}=.02\right)$ 。具体的には、 意見反映高群の方が低群よりも感情的評価が高かった（図 2)。大きな違いではないものの、実験操作前の違いであ るため、実験効果の分析において、感情的評価 $\times$ 価值類 似性 $\times$ 意見反映の交互作用項を投入し、この効果につい は統制を行う。

その次に、価值類似性と意見反映による操作が、信頼 および手続き的公正の評価へ影響を及ぼしているのか検 討を行った。1つめに、信頼の評価を従属変数に、価值類 似性（高群 vs. 低群）の 1 要因分散分析を行った（図 3)。 その結果、類似性高群 $(M=3.12, S D=.74)$ の方が類似性 低群 $(M=2.46, S D=.73)$ よりも信頼の評価が高いことが 確認された $\left(F(1,315)=63.04, p<.001, \eta_{p}{ }^{2}=.17\right)$ 。よって、 価值類似性による信頼の実験操作の妥当性が示された。2 つめに、手続き的公正の評価を従属変数に、意見反映（高 群 vs. 低群) の 1 要因分散分析を行った（図 4)。その結果、 意見反映高群 $(M=3.20, S D=.76)$ の方が意見反映低群 $(M$ $=2.55, S D=.87)$ よりも手続き的公正の評価が高いことが 確認された $\left(F(1,315)=50.94, p<.001, \eta_{p}{ }^{2}=.14\right)$ 。よって、 意見反映による手続き的公正の実験操作の妥当性が示さ れた。

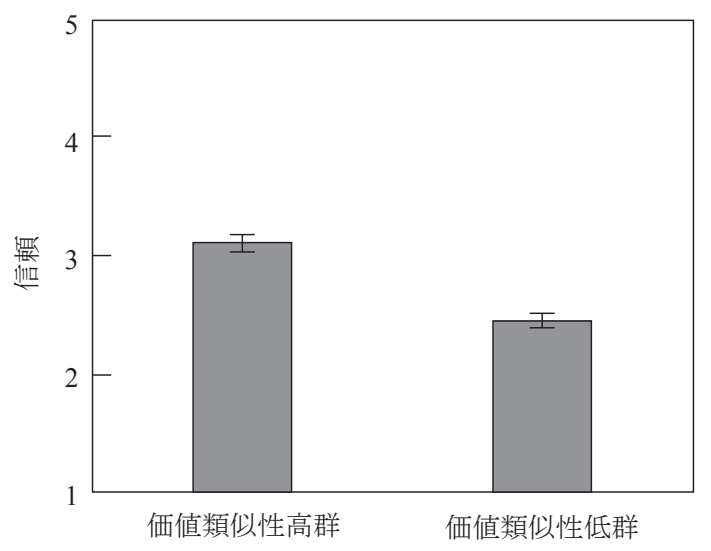

図 3 : 価值類似性の信頼への効果

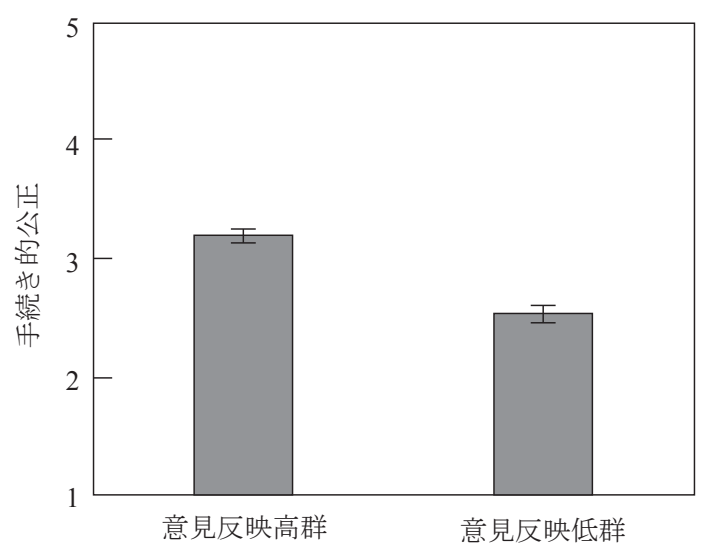

図 4 : 意見反映の手続き的公正への効果

\section{2 決定受容に対する意見反映による手続き的公正と類 似性による信頼の効果}

A 市の決定受容に対して、価值類似性による信頼と意 見反映による手続き的公正の操作を質的変数、感情的評 価を量的変数の独立変数とする一般線形モデルによる分 析を行った。なお、感情的評価 $\times$ 価值類似性 $\times$ 意見反 映の交互作用の効果を統制するため、この交互作用項も 投入した。

その結果、価值類似性 $\left(F(1,309)=31.30, p<.001, \eta_{p}{ }^{2}=\right.$ $.09)$ 、意見反映 $\left(F(1,309)=9.12, p=.003, \eta_{p}{ }^{2}=.03\right)$ 、感情 的評価 $\left(F(1,309)=122.43, p<.001, \eta_{p}{ }^{2}=.28\right)$ の主効果が 確認された。また、価值類似性 $\times$ 意見反映の交互作用が 有意傾向の水準で確認された $(F(1,309)=3.60, p=.059$, $\left.\eta_{p}{ }^{2}=.01\right)$ 。この交互作用について単純主効果の検定を行っ たところ、価值類似性低群で意見反映の単純主効果が有 意で $\left(F(1,309)=12.19, p=.001, \eta_{p}^{2}=.04\right)$ 、価值類似性 高群では意見反映の単純主効果はみられなかった（ $F(1$, $309)=.62, p=.430)$ 。すなわち、市長の価值類似性による 信頼が低い場面では、意見反映による手続き的公正が高 い条件の方が低い条件よりも決定の受容が促進されるこ とが示唆された（図 5)。

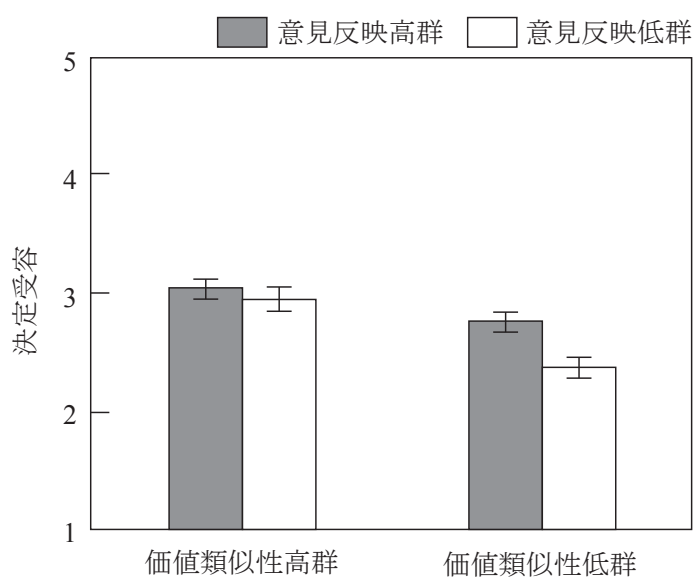

図 5 : 価值類似性の水準における意見反映の決定受容への 効果

\section{5. 考察}

HLW 地層処分施設の立地調査受容について、人々の感 情的評価と、手続き的公正の効果および信頼の効果が及 ぼす影響を検討した。その結果、感情的評価、手続き的 公正の操作、信頼の操作は、それぞれ立地調査の受容に 影響を及ぼしていた。特に、市長の価值類似性による信 頼が低い場面では、手続き的公正が高い条件の方が低い 条件よりも決定の受容が促進されることが示唆された。

感情的評価の影響は、HLW 地層処分施設は人々の忌避 的な反応が生じやすいことが指摘されており（Easterling， 2001)、HLW 地層処分施設の立地調查が求められている 地域住民にとっては, 否定的な感情が喚起されやすいと 考えられる。感情的評価は、リスク施設に対する選好 
評 価 (Keller, Visschers, \& Siegrist, 2012; Siegrist, Keller, \& Cousin, 2006）として決定受容一直接的に影響しており、 また HLW 地層処分施設の立地においても直接的影響を 与えており、本研究の結果とも整合している（大澤他, 2014)。

手続き的公正の決定受容への影響については、放射性 廃棄物の地層処分の先行研究では重要な規定因として 指摘されている（大友他, 2014; 大澤他, 2014)。Krütli et al.（2010）は、放射性廃棄物の施設立地の決定プロセス において、公正な手続きで進められているか否かが人々 の大きな関心事項であることを指摘している。本研究で も同様に，長期的な安全性が必要な HLW 地層処分施設の 立地調査を求められている地域住民は、自分達の意見が 反映されるかの手続き的公正への関心が高く, 決定受容 の判断に重要な影響を及ぼしたと考えられる。

さらに、意見反映による手続き的公正の決定受容への 影響は、価值類似性による信頼によって左右されていた。 価值類似性による信頼が低いほど、意見反映による手続 き的公正が決定受容に与える影響は強くなっていた。手 続き的公正の影響を左右する要因として、個人の価值に 対する脅威が議論されており（Skitka, 2002）、価值の脅威 にさらされる問題では、人々はより公正な判断を求める にようになり、劦威が低い問題であれば公正な判断を求 める傾向は弱くなると考えられている。HLW 地層処分施 設の立地は長期の安全性を求められることから生命に関 する価值 (不利益) に深く関わる問題であり、その価值 の類似性が低い信頼のできない市長により大きな务威に さらされると感じることにより、より手続き的に公正な 状況での判断を求めたのではないかと推察される。一方、 価值の類似性による信頼が高い場合には、価值の脅威に さらされていると感じず、公正な判断を求める傾向は弱 くなったと推察される。この結果は、広瀬・大友 (2015) が、 信頼が低いほど、手続き的公正がごみ収集料值上げの決 定受容に与える影響は強くなるという結果と同じ結果と なった。しかし、本研究で取り上げた忌避な施設の受容 も含め、その他の対象分野のリスク分野でもこのような 傾向が一般的なのか、忌避的な施設のように価值への劦 威が大きくなるほどその傾向が強くなるのかは、今回の 研究のみでは言及することはできない。

以上のように、HLW 地層処分施設の立地調査受容に対 して、感情的評価、手続き的公正、信頼が影響を及ぼす だけではなく、価值類似性による信頼が低い場面では、 より手続き的公正の影響が強くなることが示唆された。 これらのことから、HLW 地層処分施設の立地に関し、そ れらを推進する関係者の信頼が低いような初期の状況で は、意思決定者は地域住民とリスク・価值観を共有しな がら信頼を高めるとともに、リスク・価值観を共有する 場として、より手続き的公正を重視したリスク・コミュ ニケーンを行う市民参加プログラムを実施する施策が必 要になると言える。

しかし、本研究にはいくつかの課題がある。本研究では、 HLW 地層処分施設の立地調査地域の選定が進んでいない
ため、首都圈のモニターを対象として Web 調査を実施し た。そのため、実際に立地調查地域として選定された地 域のように、個人的に重要な課題と感じていない人々が 対象になっている可能性がある。これにより、感情評価 の影響が明確にでなかった可能性もある。また、公正研 究では、このような場面想定法を用いた研究の有効性が 確認されているが (Nonami et al., 2015; van den Bos, 1999; van den Bos, Maas, Waldring, \& Semin, 2003)、場面想定法に よるシナリオの操作を行ったため、現実の問題として一 般化するには限界がある。今後、実際に立地地域が選定 された段階で、対象地域にした調査研究を行い、対象と なった地域とそうでない地域との違いを検討することも 必要と考えられる。

\section{謝辞}

本研究は文部科学省科学研究費基盤 B（課題番号： 16H03011、研究代表者：広瀬幸雄）の補助を受けて実施 された。

\section{引用文献}

Besley, J. C. (2012). Does fairness matter in the context of anger about nuclear energy decision making? Risk Analysis, 32 (1), 25-38.

Cvetkovich, G. \& Nakayachi, K. (2007). Trust in a Highconcern risk controversy: A comparison of three concepts. Journal of Risk Research, 10 (2), 223-237.

Earle, T. C. (2010). Trust in risk management: A model-based review of empirical research. Risk Analysis, 30 (4), 541-574.

Earle, T. C. \& Cvetkovich, G. (1995). Social trust: Toward a cosmopolitan society. Westport. CT: Praeger Press.

Earle, T. C. \& Siegrist, M. (2008). On the relation between trust and fairness in environmental risk management. Risk Analysis, 28 (5), 1395-1414.

Easrerling, D. (2001). Fear and loathing of Las Vegas: Will a nuclear waste repository contaminate the imagery of nearby place. In J. Flynn, P. Slovic, \& H. Kunreuther (Eds.), Risk, media and stigma: Understanding public challenges to modern science and technology. London: Earthscan, 133-156.

Finucane, M. L., Alhakami, A., Slovic, P., \& Johnson, S. M. (2000). The affect heuristic in judgments of risks and benefits. Journal of Behavioral Decision Making, 13 (1), 1-17.

広瀬幸雄・大友章司 (2015). 手続き的公正と行政への信 頼がごみ収集手数料の值上げの受容に及ぼす効果. 社 会安全学研究, 5, 15-22.

経済産業省資源エネルギー庁（2018）。諸外国における高 レベル放射性廃棄物の処分について 2018 版. https:// www2.rwmc.or.jp/publications:hlwkj2018.（2018 年 11 月 15 日参照)

Keller, C., Visschers, V., \& Siegrist, M. (2012). Affective imagery and acceptance of replacing nuclear power plants. Risk Analysis, 32 (3), 464-477.

Krütli, P., Flüeler, T., Stauffacher, M., Wiek, A., \& Scholz, R. 
W. (2010). Technical safety vs. public involvement? A case study on the unrealized project for the disposal of nuclear waste at Wellenberg (Switzerland). Journal of Integrative Environmental Sciences, 7 (3), 229-244.

NEA (2013). Forum on stakeholder confidence (FSC). Retrieved at 2019 January 3, from http://www.oecd-nea.org/rwm/fsc/

Nonami, H., Hirose, Y., Ohnuma, S., Midden, C., \& Ohtomo, S. (2015). Effects of voice and similarity on procedural fairness and trust: A dual process model of public acceptance based on representatives' participation. Asian Journal of Social Psychology, 18 (3), 216-224.

大澤英昭・広瀬幸雄・大沼進・大友章司 (2014)。 フラン スにおける高レベル放射性廃棄物管理方策と地層処分 施設のサイト選定の決定プロセスの公正．社会安全学 研究, 4, 51-76.

大友章司・大澤英昭・広瀬幸雄・大沼進 (2014)。福島原 子力発電所事故による高レベル放射性廃棄物の地層処 分の社会的受容の変化. 日本リスク研究学会誌, 24 , 49-59.

Peters, M. E., Burrastonm, B., \& Mertz, K. C. (2004). An emotion-based model of risk perception and stigma susceptibility: cognitive appraisals of emotion, affective reactivity, worldviews, and risk perception in generation of technological stigma. Risk analysis, 24 (5), 1319-1367.

Siegrist, M., Keller, C., \& Cousin, M.-E. (2006). Implicit attitudes toward nuclear power and mobile phone base stations: Support for the affect heuristic. Risk Analysis, 26 (4), 10211029.

Skitka, L. J. (2002). Do the means always justify the ends, or do the ends sometimes justify the means? A value protection model of justice reasoning. Personality and Social Psychology Bulletin, 28 (5), 588-597.

鈴木晃志郎 (2011). NIMBY 研究の動向と課題. 日本観 光研究学会第 26 回全国大会論文集, 17-20.

van den Bos, K. (1999). What are we talking about when we talk about no-voice procedures? On the psychology of the fair outcome effect. Journal of Experimental Social Psychology, 35 (6), 560-577.

van den Bos, K., Maas, M., Waldring, I. E., \& Semin, G. R. (2003). Toward understanding the psychology of reactions to perceived fairness: The role of affect intensity. Social Justice Research, 16 (2), 151-168.

Visschers, V. H. M. \& Siegrist, M. (2013). How a nuclear power plant accident influences acceptance of nuclear power: Results of a longitudinal study before and after the Fukushima disaster. Risk Analysis, 33 (2), 333-347.

(受稿 : 2019 年 2 月 14 日 受理 : 2019 年 5 月 20 日)
Appendix $1:$ HLW 地層処分の立地調査に関する仮想的場 面の設定のシナリオ

あなたが、A市の市民だと想像して以下の文章をお読 み下さい。

A 市では、現在、過疎による人口減少と厳しい財政不 足の状況にあります。

このままでは教育・福祉のサービスも低下し、道路や 下水道などの維持も困難です。 $\mathrm{A}$ 市の市長は、何らかの 対策を講じなければならないと頭を抱えていました。

この A 市に対して、政府から「高レベル放射性廃棄物 の地層処分場の候補地になるための立地調查の受け入れ」 の要請がありました。

立地調査を受け入れた場合、地域共生事業として A 市 にはさまざまな交付金が支給されます。そこで、A市の 市長はこの要請を受け入れるか否か検討することにしま した。

Appendix 2 : 意見反映による手続き的公正の操作のシナリ 才文

高群 ; 地層処分場の立地調査の受け入れの是非の決め方 について

$\mathrm{A}$ 市での地層処分場の立地調査に際して、立地候補と なる地域の市民から、高レベル放射性廃棄物の地層処分 場の安全性への懸念や、「放射能のまち」と見られるといっ た風評被害への不安が生じると予想されます。

A 市の市長は、議会での議決を得るとともに、市民一 の説明会を開き、市民の意見を聴き、その意見を尊重して、 地層処分場の立地調査の受け入れの是非を決める手続き で進めていく方針を打ち出しています。

低群 ; 地層処分場の立地調査の受け入れの是非の決め方 について

A 市での地層処分場の立地調査に際して、立地候補と なる地域の市民から、高レベル放射性廃棄物の地層処分 場の安全性への懸念や、「放射能のまち」と見られるといっ た風評被害への不安が生じると予想されます。

A 市の市長は、議会での議決を得るとともに、市民一 の説明会を開くものの、市長自身の判断で、地層処分場 の立地調査の受け入れの是非を決める手続きで進めてい く方針を打ち出しています。

Appendix 3 : 類似性による信頼の操作のシナリオ

高群 ; A 市の市長ついて

㛜しい財政状況に絁んでいるA 市の市長は、『A 市の発 展についてあなたとは同じような』の意見の持ち主です。

低群 ; A 市の市長ついて

㛜しい財政状況に悩んでいる A 市の市長は、『A市の発 展についてあなたとは違った』の意見の持ち主です。 